The different types of equipment used and different approaches to the geological comparisons were compared and contrasted during an exchange of visits between the Hudson Laboratories group and a party from Bedford Institute of Oceanography, which included Professor Chesterman. The Hudson Laboratories party, which had full access to bottom data based on direct visual observation, and a slightly less sophisticated sonar system, felt keenly the amount of information which was not displayed on the records. The B.I.O. groups, on the other hand, whose previous "detailed" information about the bottom was based on standard oceanographic sampling on grids of various dimensions, were much impressed by how much more about the bottom was revealed by the Kelvin-Hughes lateral echo sounder. The obvious conclusion from this comparison is that side-looking sonar is not "magic," but does provide much more information about the bottom than can be obtained by standard surveying techniques, and does so in much less time and with greater detail.

Acknowledgments

This work was supported by the OFFICE OF NAVAL RESEARCH under Contract Nonr-266(84). Reproduction in whole or in part is permitted for any purpose of the United States Government. It is Hudson Laboratories of Columbia University Contribution No. 250.

A Periglacial Eolian Sand at Debert, Northern Nova Scotia: a Preliminary Report.*

DONAID J.P. SWIFT

Department of Geology, Dalhousie University, Halifax, N.S. DOUGLAS S. BYERS

Robert S. Peabody Foundation for Archaeology, Phillips Academy, Andover, Mass.

and DAVID KRINSLEY

Queens College, Flushing N.Y.

Description of the Sand

Excavation of a paleo-Indian site at Debert, northern Nova Scotia (Figure 1), has revealed the presence of a localized sand body of periglacial origin.

The site is underlain by friable, dusky red Triassic sandstone (Wolfville Formation of KLEIN, 1962). The sandstone is moderately to well sorted, and is locally conglomeratic.

Bedrock is mantled by a dusky red, sandy till of local derivation, ranging from 0 to 5 metres thick. The uppermost metre of the till contrasts lithologically with the lower portion at many places. It 


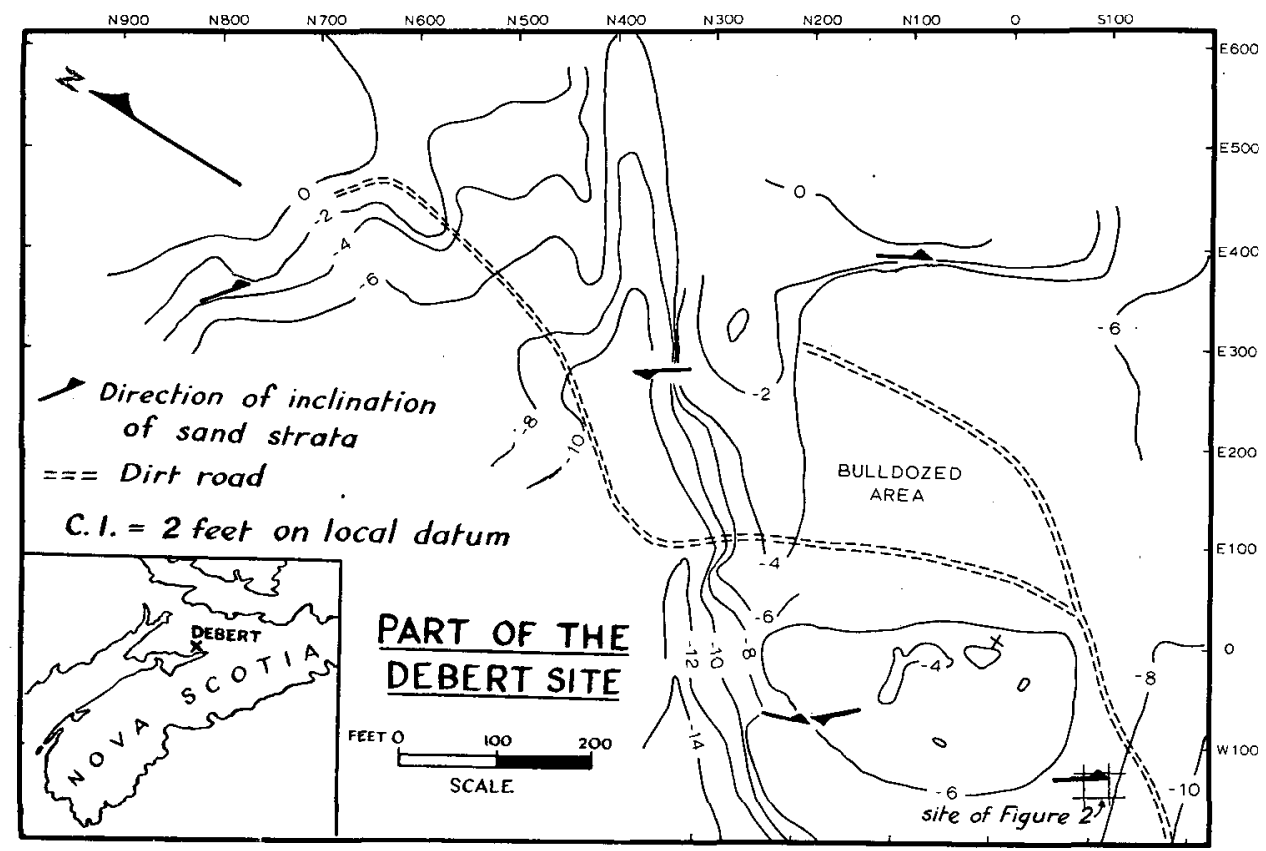

Figure 1. Contour map of Debert Site, showing dip directions of inclined strata.

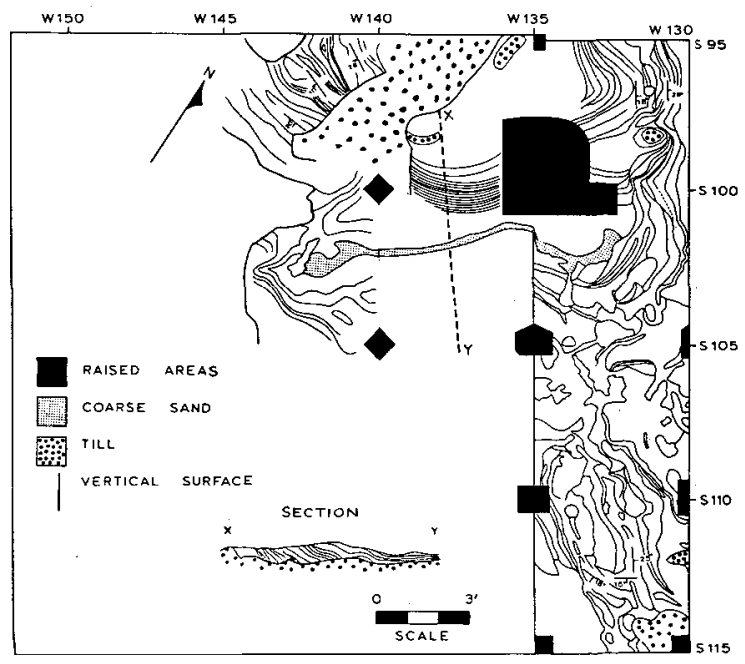

Figure 2. Detail of stratification in a portion of the Debert excavations. (location shown on Figure 1). Raised areas are pilasters left standing by archaeologists during excavation to indicate the nature of the removed strata. Blank areas indicate that the stratified sand is covered or that the strata are too vague to map. The irregular strata on the lower right have been disturbed by tree roots and the overturning of trees by the wind. 
contains local concentrations of gravel, and zones where sand and clay have been separated into poorly-defined strata. This upper portion is considered to be an ablation till.

At the Debert site, the till is overlain by 0 to 2 metres of very thin-bedded to laminated, reddish brown fine-grained sand, containing up to $8 \%$ of silt and clay. The strata are homolithic (only one lithology present). They are dominantly flat-1ying, but at some exposures are undulating, with dips up to $20^{\circ}$. Such undulations may be 2 metres wide. They may contain localized areas of steep dips (up to and exceeding $75^{\circ}$ ). Stratification may be locally faint or missing. Continuity of the strata is estimated to be 1 to 10 metres. The stratified sand outcrops within an area of one square kilometre.

A podzol soil profile developed on the stratified sand contains paleo-Indian artefacts. Thirteen radiocarbon dates from charcoal were determined by ROBERT STUCKENRATH of the ADVANCED SCIENCE CENTER FOR ARCHAEOLOGY, THE UNIVERSITY MUSEUM, Philadelphia: they average $10,600 \pm 47$ B.P., or during Valders time of the mid-continent sequence. The last ice sheet in the area has been tentatively correlated with the sheet which constructed the coastal moraine of Maine and New Brunswick (BORNS, 1965). A date of $13,325 \pm 500$ B.P. has been obtained for this latter feature (WALTON et al., 1961). The stratified sand therefore developed within a period of approximately 2,700 years, during Port Huron and Two Creeks time of the mid-continent sequence.

\section{Depositional Agent}

The stratigraphic setting, lithology and stratification of the sand body indicates that it is some sort of stratified drift or similar periglacial deposit. Possible depositional agents therefore are:

$$
\begin{aligned}
& \text { 1. Glacio-marine } \\
& \text { 2. Glacio-lacustrine } \\
& \text { 3. Glacio-fluvial } \\
& \text { 4. Eolian }
\end{aligned}
$$

Comparison with nearby glacio-marine, glacio-fluvial and blaciolacustrine deposits suggests that the sand was not the product of aqueous sedimentation. All of these deposits are characterized by one or more of the following strata types in addition to strata of sand:

1. Strata of plastic clay, indicative of the sedimenting of suspended material from standing water.

2. Lenses or layers of gravel, indicative of sedimentation by stream flooding.

The Debert strata, on the contrary, are composed wholly of sand. This restriction of the strata to sand, however, does not conflict with the principles of eolian sedimentation. By virtue of its extremely low viscosity, air is an extremely efficient sorting agent. In winddominated areas, gravel is left as a lag at the source, sand is moved by traction to a nearby site of deposition, and the fines are carried by suspension to great distances (BAGNOLD, 1941). 
The following points are positive indications of eolian sedimentation:

1. Medians of bulk samples and of single laminae are almost entirely confined to the fine sand class, as noted by BAGNOLD (1941, p.6) for Libyan dune sands, and WENTWORTH (1931, p.12-17) for American dune sands.

2. The homolithic stratification resembles that described by Bagnold (1941, p.236-246) from the Libyan desert. Bagnold attributes each layer to a sangle episode of wind.

3. Pebbles resembling ventifacts are present at the sand-till interface. However, their origin has not yet been conclusively established.

Paleocurrent indicators also suggest eolian transport. Azimuths of the direction of inclination of strata were determined at six stations (see Figure 1). At some stations, the stratification was very irregular, and an average of three to five values was used. Areas of extremely gentle dip and areas where the stratification has been disturbed by tree roots were not considered; consequently data is lacking over a considerable portion of the site.

The mean azimuth for all stations was found to be $141^{\circ}$ on a $180^{\circ}$ basis. Examination of the sand-till interface suggests that the strata are mainly foreset beds deposited by a northwest wind. The paleocurrent system, then, was normal to the small valley seen in the middle of Figure 1. The valley, the dry head of a local stream, is cut into till and is blanketed by the stratified sand. It is therefore easier to relate the paleocurrent data to a hypothetical late Pleistocene wind direction than it is to the late Pleistocene stream net.

Finally, an eolian origin is indicated by electron microscopy. Examination of the surface texture of sand grains by Krinsley reveals the curved, conchoidal fractures characteristic of eolian sands (KRINSLEY et al., 1964). Eolian action appears to have been intensive.

Development of the Sand

The relatively large admixture of silt and clay in the sand may show that it was derived directly from the sandy till of the area, rather than from outwash, the more common source of periglacial eolian material. A till source might result in an inherited bias towards the fines, unless transport was so prolonged as to eliminate this characteristic, and the small size of the deposit suggests a local source. However, periglacial eolian sands in New England are also silty (SCHAFER and HARTSHORN, 1965), and they have been attributed to the deflation of outwash. Circumstantial evidence suggests an in situ origin; the nearest outwash to the north is several kilometres away, and the intervening areas contain no eolian deposits.

Sedimentation appears to have begun after meltwater and rainwash made available a thin, patchy film of sand on the till surface. Sandblasting with this lag deposit accelerated the erosion of the till, and released till materials for redistribution by the wind and further sandblasting. Deposition continued until a nearly continuous blanket of flat-lying to undulating strata was produced. Some of the dune-like 
undulations were clearly localized by irregularities in the till (see Figure 2). Other aspects of these structures may be explained by analogy with the modern surface: the Debert site is an open heath, partly as a consequence of its good internal drainage, and partly due to recent bulldozing activity. A shrubby plant cover consists of gray birch, and such ericaceous species as lambkill, Rhodora, low bush blueberry, Erica, and teaberry (LYFORD, 1964); expanses of wind-rippled sand or bare till are present between hummocks of vegetation. Similar plant growth may have been partly or completely responsible for the localization of some of the dune-like structures at time of formation. Evidence consists of masses of structureless sand, locally bordered by sand strata with dips exceeding $75^{\circ}$. These features may have been created by sand-trapping hummocks of vegetation, similar to those on the modern surface. Analogy with modern beach dunes suggests that under springtime conditions, sand and silt blew from well-drained areas onto the damp sides of hummocks now represented by the masses of structureless sand. The resulting peripheral strata were able to retain their excessive dips until stabilized by plant growth or burial.

Free-moving dunes appear not to have developed. Diastems are recognizable at several locations, but are most easily explained as episodes of deflation during the depositional period. The angular unconformities between foreset and backset strata that characterize deposition by mobile sand waves are not present. Evidence of sandblasting was noted on only a very few artefacts. It is therefore assumed that strong wind action had ceased before the site was occupied.

\section{Significance of the Sand}

The Debert eolian sand is of immediate interest to archaeologists of the ROBERT S. PEABODY FOUNDATION FOR ARCHAEOLOGY, who are reconstructing the history of the site (BYERS, 1965). Since the Debert sand can be established as eolian on the general grounds cited above, it is also of interest to sedimentologists as a proving ground for tests of eolian versus aqueous deposition. Most tests of this sort have been developed by comparing beach and dune sands in which the eolian sand has undergone intensive pre-sorting, or by studying desert sands which have undergone prolonged eolian reworking. The eolian sand at Debert comes from a poorly sorted source, and transportation was brief. Size frequency distribution studies, further studies of grain surface textures, quantitative analysis of the stratification, and other tests are being applied to the Debert sand in order to determine the sensitivity of these techniques for demonstrating eolian sedimentation of the Debert type.

\section{References cited}

BORNS, H., 1965, Late glacial ice wedge casts in northern Nova Scotia, Canada: Science, v. 148, p. 1223-1226.

BAGNOLD, R。A., 1941, The physics of blown sand and desert dunes: London, Methuen, $265 \mathrm{p}$.

BYERS, D.S。, 1965, The Debert archaeological project: Maritime Sediments, v。1, p. 19-20。 
KLEIN, G。DeV., 1962, Triassic sedimentation, Maritime Provinces, Canada: Geol. Soc. America Bul1. v. 73, p. 1127-1146.

KRINSLEY, D。, TAKAHASHI, T., SILBERMAN, M。L., and NEWMAN, W.S。, 1964 , Transportation of sand grains along the Atlantic shore of Long Island, New York - an application of electron microscopy: Marine Geology, v。2, p. 100-120。

LYFORD, $\mathrm{W}_{0} \mathrm{H}_{\bullet}, 1964$, Notes on the soil at the Debert Archaeology Site, Debert, Nova Scotia: unpublished report, Harvard Forest, Petersham, Mass。

SCHAFER, J..P , and HARTSHORN, J.. H., 1965, The Quaternary of New England, p. 113-128, in WRIGHT, H.E., Jr., and FREY, D.G., Editors, The Quaternary of the United States: Princeton, The Princeton University Press, 922p.

WALTON, A., TRAUTMAN, M.A., and FRIEND, J.P., 1961, Am. Jour. Sci. Radiocarbon Supplement, v. 3, p. 47.

WENTWORTH, C.K., 1931, The mechanical composition of sediments in graphic form: Iowa Univ. Studies in Natural History, v. 14.

\section{The Hudson Bay Project*}

B.R. PELLETIER

Bedford Institute of Oceanography, Dartmouth, N.S.

Marine geological work in Hudson Bay was undertaken in 1961 and 1965. The writer took part in both cruises, accompanied on the first by his former colleague DR. R. J. LESLIE. The studies included investigation of raised beaches, bathymetry, water chemistry, investigations of both planktonic and benthonic organisms, current measurements, bottom photography and bottom sampling by means of snapper samplers, dredges and cores. Geophysical research to support the project was also carried out with the aid of both bottom and surface gravimetry, air and sea-borne magnetometers, deep crustal and shallow seismic surveys, and sub-bottom profiling in unconsolidated sediments as we11 as bedrock structures. The M/V Theta..(in 1961), the M/V Theron and the CSS Hudson (in 1965), launches, a helicopter and a North Star four-engined aircraft were used to support the overall project.

Bathymetric contours are concentric to the periphery of the bay, ranging down to approximately 200 metres. Long submarine ridges and valleys disrupt the uniform saucer-shaped appearance of the floor of the bay, and this is further dissected by a submerged Tertiary drainage system.

Bottom sediments in Hudson Bay are generally coarser in shoal and peripheral areas. Ice-rafted sediments tend to mask the normal marine 